The International Journal of Banking and Finance, Volume 8 (Number 3), 2011: pages 73-88

\title{
CUSTOMER ADOPTION OF BANKING TECHNOLOGY IN PRIVATE BANKS OF INDIA
}

\author{
Bindiya Tater, Manish Tanwar, and Krishna Murari \\ Suresh Gyan Vihar University-Jaipur, Rampuria Jain College and MITS University, India
}

\begin{abstract}
This paper explores the perception of Indian customers towards the use of technologies with respect to such factors as convenience, privacy, security, ease of use, real time accessibility, and accurate record of varied transaction that enable customer's adoption of Banking Technology. Other factors such as slow transfer speed, technical failure, frauds and unawareness among customers that make hindrance in adoption, are also tested. The results show that demographic variables such as gender, age, qualification and income play a positive role in adoption of banking technology. All the banks are using information technology as a strategic vehicle to stay competitive against other players. There is no significant difference between adoption rates of banking technologies by the customers of different private banks. The paper also shows that banking technology helps in increasing customer satisfaction, customer loyalty, improvised growth, and performance of the banks.
\end{abstract}

Keywords: Private banks, Technical failures, ATM, Branch, Internet and mobile banking, Kruskal Wallis test, Chi-square test

JEL Classification: G 21

\section{Introduction}

The banking industry in India is steadily expanding. The liberalization of the economy has created a competitive culture that has taken the service industry and particularly the banking industry by storm. The banking sector has been the backbone of every emerging country. It implements and brings about economic reforms. Any change in this sector through technology adoption has a sweeping impact on a country's growth. The development in information collection, storage, processing and transmission technologies have influenced all aspects of the banking activity. 
Information technology is a medium that has revolutionized banking and everyday bank operations at the click of a button thus enabling sophisticated product development, better market infrastructure, implementation of reliable techniques for control of risks and reaching geographically distant and diversified markets (Marion 2008).

Banking Technology offers benefits to both banks and customers. Pikkarainen et al. (2004) mention two fundamental reasons underlying banking technology development and penetration. First, the bank gets significant cost savings in their operation through e-Banking services. It has been proven that online banking channel is the cheapest delivery channel for banking products once established. Secondly, the banks have reduced their branch networks and downsized the number of service staff which paved the way to self-service channels. Customers too enjoy self-service, freedom from time and place constraint and reduced stress of queuing in banking hall. It was indicated that electronic banking services delivery are the cheapest and the most profitable and wealthiest delivery channel for banking products.

This paper is organized as follows. Section 2 attempts a quick review of the literature on this topic. In section 3, we describe the methodology adopted for this empirical work. The results are presented thereafter in sections 3 and 4 with the latter section providing statistical tes results. The paper ends in section 6 as conclusion.

\section{Literature Review}

Most studies found to-date focuses on the individual banking technologies and the customer satisfaction level used in the case of banks. For example Mobarek (2007) in his study in Botswana region pointed out that the delivery channels are lacking in meeting the demands of the customer by not making them aware of e-banking and up-to-date technology. The hypotheses were tested, which showed that there is a relationship between age group, occupation and some aspects of e-banking.

Another study by Islam, Sheel and Biswas (2007) investigate the satisfaction levels of HSBC ATM cardholders (both staff and non-staff) with respect to various aspects (for instance, promptness of card delivery, the performance of HSBC ATM, and the service quality of ATM personnel) of using HSBC ATM and their opinions on various other related issues such as positive and inconvenient features of HSBC ATM, recommendation to improve the service quality. The findings provide significant results related to use and worth of holding the ATM. 
Further, the findings helped the ATM section to identify their positive and negative features and the customer recommendation.

Wan et al. (2005) study the customers' adoption of banking channels in Hong Kong. They covered four major banking channels namely ATM, Branch Banking, Telephone Banking and Internet Banking. The study segmented the customers on demographic variables and psychological beliefs about the positive attributes processed by the channels. The psychological factors were ease of use, transaction security, transaction accuracy, speediness, convenience, time utility, provision of different personal services, social desirability, usefulness, economic benefits, and user involvement.

Another study investigated inhibitors and enablers of internet banking in Oman, comparing this to the situation in Australia. Data were collected from interviews with bank managers in each country, based on a consideration of each bank manager's perceptions of four factors that might affect their decisions to adopt internet technologies: relative advantage, organizational performance, customer/organizational relationship and ease of use. It is hoped that the results will be useful in seeing why Omani banks have been slow to adopt internet technology and helps to encourage them to make the change.

There are several competitive advantages associated with the adoption of technology in the banking sector, including the creation of entry barriers, enhancement of productivity, and increased revenue generation from new services (Fitzsimmons and Fitzsimmons, 1997). Delivery methods have become an increasingly important technique to retain customers in today's dynamic banking environment since customers can make withdrawals, deposits and access balances at their own convenience (Tanzi, 1997).

The importance of security and privacy for the acceptance of online banking has been noted in many banking studies (Sathye, 1999; Hamlet and Strube, 2000; Tan and Teo, 2000; Polatoglu and Ekin, 2001; Black et al., 2002; Giglio, 2002; and Howcroft et al., 2002).

Roboff and Charles (1998) found that people have a weak understanding of online banking security risks although they are aware of the risks. Furthermore, they found that consumers often trust that their bank is more concerned about privacy issues and will protect them. Finally, they argue that although consumers' confidence in their bank is strong, their confidence in technology is weak. 


\section{Research Methodology}

\subsection{Objective of the Study}

This paper focuses on exploring the four major factors that influence the adoption of information technology in private banks of India. These factors are: the variables that enable and inhibit customer's adoption for banking technology; influence of demographic variables on banking technology adoption; and level of customer satisfaction with banking technology. The paper also examines the variables associated with ATM banking, branch banking, internet banking and mobile banking.

\subsection{Hypotheses of the Study}

Eight null hypotheses (starting with $\mathrm{H}_{01}, \mathrm{H}_{02} \ldots$ ) and alternate hypotheses (starting with $\mathrm{H}_{\mathrm{a} 1}, \mathrm{H}_{\mathrm{a} 2}$ ) are formulated. Tested results of these hypotheses are presented in the section 5 of this study.

$\mathbf{H}_{\mathbf{0 1}}$ : Usefulness of banking services is same for all the banks.

$\mathbf{H}_{\mathrm{a} 1}: \mathrm{H}_{01}$ is not true.

$\mathbf{H}_{\mathbf{0 2}}$ : There is a significant difference between characteristics of ATM banking services provided by different private banks to the customers.

$\mathbf{H}_{\mathbf{a} 2}: \mathrm{H}_{02}$ is not true.

$\mathbf{H}_{\mathbf{0 3}}$ : There is a significant difference between branch banking services and customer satisfaction.

$\mathbf{H}_{\mathbf{a} 3}: \mathrm{H}_{03}$ is not true.

H04: There is a significant difference between internet banking services and customer satisfaction.

$\mathbf{H}_{\mathbf{a} 4}: \mathrm{H}_{04}$ is not true.

$\mathbf{H}_{\mathbf{0 5}}$ : There is a significant difference between mobile banking services and customer satisfaction. 
$\mathbf{H}_{\mathbf{a 5}}: \mathrm{H}_{05}$ is not true.

$\mathbf{H}_{\mathbf{0 6}}$ : There is a significant difference between adoption of Information Technology and Customer satisfaction.

$\mathbf{H}_{\mathbf{a} 6}: \mathrm{H}_{06}$ is not true.

$\mathbf{H}_{07}$ : There is a significant difference between customer adoption and benefits of IT banking services for all four private banks.

$\mathbf{H}_{\mathbf{a} 7}: \mathrm{H}_{07}$ is not true.

$\mathbf{H}_{\mathbf{0 8}}$ : There is a significant difference between unwillingness to use e-channel and customer rejection for all four banks.

$\mathbf{H}_{\mathbf{a 8}}: \mathrm{H}_{08}$ is not true.

\subsection{Sample and Tools for Data Analysis}

This study is conducted using respondents involved with four private sector banks (ICICI, HDFC, AXIS, and INDUSIND) in India from Bikaner to Jaipur regions of Rajasthan. Descriptive research methodology is used to accomplish the objectives using random and convenience sampling techniques. A questionnaire was designed consisting of the following four parts.

Part 1: Demographic profile of the Respondents,

Part 2: Customer's account profile of the Respondents,

Part 3: Personal Characteristics of customers with different banking services, and

Part 4: Characteristic and usefulness of different banking services.

A five point Likert scale is used to elicit responses to the questionnaire. The data are collected from 500 bank customers (ICICI Bank-154, HDFC Bank- 88, AXIS Bank- 77, INDUSIND Bank- 84) through structured questionnaire method out of which 403 responses are obtained. The data collected are tabulated and analyzed for the purpose of giving precise and concise information. Descriptive frequency statistical tool is adopted for interpretation and hypothesis 
testing is done using Kruskal Wallis and chi-square tests as appropriate for non-parametric statistics applied to survey data analysis.

\section{Empirical Results}

Tables 1 through 4 show the demographic descriptive statistics of the respondents from the selected banks. Gender as a personal variable was found to have a significant role in customer's banking technology adoption. From the Table 1, it is found that ICICI, HDFC, AXIS and INDUSIND bank's male respondents are five times more as users as compared to female respondents. Females are still comparatively lacking banking habits.

Table 1: Demographic profile of the respondents

\begin{tabular}{|l|l|c|c|c|c|}
\hline $\begin{array}{l}\text { Demographic } \\
\text { Variables }\end{array}$ & Categories & ICICI (\%) & HDFC (\%) & AXIS (\%) & \multicolumn{2}{l|}{ INDUSIND } \\
(\%)
\end{tabular}

Note: Figures in parenthesis denotes \% to column total.

Source: Primary data from questionnaire and interviews.

Qualification is the factor that makes the customer aware of the banking technology and also helps them in easy adoption. Among the four banks, about 27 per cent of AXIS Bank respondents belong to the qualification category of undergraduate: this could proxy for income effect since educated persons earning more money are likely to use banking. Thirty-four per cent of ICICI, 32 per cent of HDFC, 31 percent of AXIS and 29 per cent of INDUSIND bank customers belong to the qualification category of graduate while 52 per cent of HDFC, 47 per cent of ICICI, 46 per cent of INDUSIND and 42 per cent of AXIS bank customers belong to the qualification category of post-graduate.

The survey reflects that about 25 per cent of ICICI bank respondents, 24 per cent of HDFC bank respondents, 23 per cent of AXIS bank respondents and 14 per cent INDUSIND bank respondents belong to the monthly income category of less than Indian Rupees=Rs 10,000.00; 38 per cent of ICICI and AXIS bank respondents belong to the monthly income 
category of Rs10,000-20,000; 44 per cent of INDUSIND, 32 per cent of HDFC, 27 per cent of AXIS and 22 per cent ICICI bank respondents belong to the monthly income category of Rs 20,001-35,000; and 16 per cent of ICICI and HDFC bank, 13 per cent of AXIS and 7 per cent INDUSIND bank respondents belong to the monthly income category of Rs 35,001 and above.

Table 2 represents the statistics of the respondents about the form of association with the banks. From the table it was found that 56 per cnt of respondents having current account and 44 per cent of respondents having saving account belongs to ICICI bank, 18 per cent of respondents having current account and 82 per cent of respondents have saving account belongs to HDFC bank, 38 per cent of respondents having current account and 63 per cent of respondents have saving account belongs to AXIS bank, 32 per cent of respondents having current account and 68 per cent of respondents have saving account belongs to INDUSIND bank.

Table 2: Association of the respondents with bank

\begin{tabular}{|l|l|c|c|c|c|}
\hline $\begin{array}{l}\text { Customer's } \\
\text { account } \\
\text { Variables }\end{array}$ & Categories & ICICI (\%) & HDFC (\%) & AXIS (\%) & $\begin{array}{l}\text { INDUSIND } \\
(\%)\end{array}$ \\
\hline $\begin{array}{l}\text { Type of } \\
\text { account }\end{array}$ & Current & $87(56)$ & $16(18)$ & $29(38)$ & $27(32)$ \\
\hline Time of & $<2$ yr & $67(44)$ & $72(82)$ & $48(63)$ & $57(68)$ \\
association & $2-4$ yrs & $62(34)$ & $38(43)$ & $27(35)$ & $31(37)$ \\
with Banks & 4 yrs \& above & $38(25)$ & $27(31)$ & $37(48)$ & $36(42)$ \\
\hline $\begin{array}{l}\text { Frequency of } \\
\text { visit to Banks }\end{array}$ & Everyday & $39(25)$ & $31(35)$ & $24(31)$ & $31(37)$ \\
& $2-3$ times per week & $46(30)$ & $34(39)$ & $19(25)$ & $26(31)$ \\
& $1-2$ times per Month & $69(45)$ & $23(26)$ & $34(44)$ & $27(32)$ \\
\hline Access of & ATM Banking & $56(36)$ & $32(36)$ & $32(42)$ & $35(42)$ \\
Electronic & Branch Banking & $43(28)$ & $30(34)$ & $24(31)$ & $20(24)$ \\
Banking & Internet Banking & $31(20)$ & $14(16)$ & $13(17)$ & $18(21)$ \\
services & Mobile banking & $24(16)$ & $12(14)$ & $8(10)$ & $11(13)$ \\
\hline
\end{tabular}

Note: Figures in parenthesis denote $\%$ to column total.

Source: Primary data from questionnaire and interviews.

The length of association represents the state of connection of customer and bank. The result shows that most of respondents have 2-4 years of association with their banks. People have long periods of relationship with Public Bank since Private Banks are new. So, the length of association is less and these banks need to generate more publicity among customers about their products and services. The longer the duration of holding an account with the banks, the more trust is developed which adds to customers' satisfaction. From the numbers in Table 2, it is found that about 45 per cent of ICICI bank respondents visit the banks 1-2 times per month, 39 
per cent of HDFC Bank respondents visit 2-3 times per week while 44 per cent of INDUSIND bank respondents visit 1-2 times per month.

The survey reflects that for ICICI, 36 per cent of respondents prefer ATM banking, 28 per cent prefer branch banking, 20 per cent prefer internet banking and 16 per cent prefer mobile banking. Similarly for HDFC: 36 per cent prefer ATM banking, 34 percent branch banking, 16 per cent internet banking and 14 per cent mobile banking. In the AXIS bank, 42 per cent of respondents prefer ATM banking, 31 per cent branch banking, 17 per cent internet banking and 10 per cent mobile banking. About 42 per cent of respondents prefer ATM banking, 24 per cent branch banking, 21 per cent internet banking and 13 per cent mobile banking in the case of INDUSIND bank. The result shows that ATM and branch banking remain as the two popular banking services.

Table 3 shows the customer adoption of technology on the basis of demographic features.

Table 3: Age and banking technology adoption

\begin{tabular}{|c|c|c|c|c|c|c|c|c|c|c|c|c|}
\hline \multirow[b]{2}{*}{ Variables } & \multicolumn{3}{|c|}{ ICICI (\%) } & \multicolumn{3}{|c|}{ HDFC (\%) } & \multicolumn{3}{|c|}{ AXIS (\%) } & \multicolumn{3}{|c|}{ INDUSIND (\%) } \\
\hline & 18-30 & $30-45$ & $45+$ & 18-30 & $30-45$ & $45+$ & 18-30 & $30-45$ & $45+$ & 18-30 & $30-45$ & $45+$ \\
\hline $\begin{array}{l}\text { ATM } \\
\text { Banking }\end{array}$ & $\begin{array}{c}18 \\
(32.1)\end{array}$ & $\begin{array}{c}28 \\
(50.0)\end{array}$ & $\begin{array}{c}10 \\
(45.5)\end{array}$ & $\begin{array}{c}15 \\
(46.9)\end{array}$ & $\begin{array}{c}12 \\
(37.5)\end{array}$ & $\begin{array}{c}5 \\
(15.6)\end{array}$ & $\begin{array}{c}13 \\
(37.1)\end{array}$ & $\begin{array}{c}14 \\
(40.0)\end{array}$ & $\begin{array}{c}8 \\
(22.9)\end{array}$ & $\begin{array}{c}13 \\
(37.1)\end{array}$ & $\begin{array}{c}14 \\
(40)\end{array}$ & $\begin{array}{c}8 \\
(22.9)\end{array}$ \\
\hline $\begin{array}{l}\text { Branch } \\
\text { Banking }\end{array}$ & $\begin{array}{c}13 \\
(30.2)\end{array}$ & $\begin{array}{c}21 \\
(48.8)\end{array}$ & $\begin{array}{c}9 \\
(20.9)\end{array}$ & $\begin{array}{c}13 \\
(43.3)\end{array}$ & $\begin{array}{c}14 \\
(46.7)\end{array}$ & $\begin{array}{c}3 \\
(10.0)\end{array}$ & $\begin{array}{c}6 \\
(30.0)\end{array}$ & $\begin{array}{c}10 \\
(50.0)\end{array}$ & $\begin{array}{c}4 \\
(20.0)\end{array}$ & $\begin{array}{c}6 \\
(30)\end{array}$ & $\begin{array}{c}10 \\
(50)\end{array}$ & $\begin{array}{c}4 \\
(20)\end{array}$ \\
\hline $\begin{array}{l}\text { Mobile } \\
\text { banking }\end{array}$ & $\begin{array}{c}6 \\
(19.4)\end{array}$ & $\begin{array}{c}17 \\
(54.8)\end{array}$ & $\begin{array}{c}8 \\
(25.8)\end{array}$ & $\begin{array}{c}7 \\
(50.0)\end{array}$ & $\begin{array}{c}4 \\
(28.6)\end{array}$ & $\begin{array}{c}3 \\
(21.4)\end{array}$ & $\begin{array}{c}8 \\
(44.4)\end{array}$ & $\begin{array}{c}8 \\
(44.4)\end{array}$ & $\begin{array}{c}2 \\
(11.1)\end{array}$ & $\begin{array}{c}8 \\
(44.4)\end{array}$ & $\begin{array}{c}8 \\
(44.4)\end{array}$ & $\begin{array}{c}2 \\
(11.1)\end{array}$ \\
\hline $\begin{array}{l}\text { Internet } \\
\text { Banking }\end{array}$ & $\begin{array}{c}5 \\
(20.8)\end{array}$ & $\begin{array}{c}10 \\
(41.7)\end{array}$ & $\begin{array}{c}9 \\
(37.5)\end{array}$ & $\begin{array}{c}7 \\
(58.3)\end{array}$ & $\begin{array}{c}1 \\
(8.3)\end{array}$ & $\begin{array}{c}4 \\
(33.3)\end{array}$ & $\begin{array}{c}4 \\
(36.4)\end{array}$ & $\begin{array}{c}4 \\
(36.4)\end{array}$ & $\begin{array}{c}3 \\
(27.3)\end{array}$ & $\begin{array}{c}4 \\
(36.4)\end{array}$ & $\begin{array}{c}4 \\
(36.4)\end{array}$ & $\begin{array}{c}3 \\
(27.3)\end{array}$ \\
\hline
\end{tabular}

Note: Figures in parenthesis denote $\%$ to column total.

Source: Primary data from questionnaire and interviews.

Banks in India have adapted and continue to adopt different technologies. Customers were asked to indicate the various technologies their banks have adopted. This was queried to know if the customers are aware of the technologies provided by their banks. Four common technologies were selected: ATM, branch banking, internet banking, and mobile banking. From the tables, it is found that both male and female customers of ICICI belonging to the 30-45 years age category are seen to favor ATM banking, branch banking, internet banking and mobile 
banking. It shows younger customers belonging to the 30-45 years are tech-savvy and find these services comfortable, to be friendly and easy to use.

Customers from different educational background were asked to indicate the various technologies they like to adopt. Four common technologies selected to present the variables include ATM, branch banking, internet banking, and mobile banking. The variables are labeled in four banks and the result is presented in Table 4.

From the Figures shown in the table, it is found that both male and female post-graduate customers of ICICI bank favor ATM banking, branch banking, internet banking and mobile banking. The study shows that higher qualification is associated with bringing attention towards new tech-banking services and qualification is a factor found to be relevant. It shows that majority of post-graduate and graduate customers favor ATM banking followed by mobile banking, branch banking and Internet banking. Customers with post-graduate and graduate qualifications are mostly adopters of IT banking services

Table 4: Educational qualification and banking technology adoption

\begin{tabular}{|l|c|c|c|c|c|c|c|c|c|c|c|c|}
\hline & \multicolumn{3}{|c|}{ ICICI (\%) } & \multicolumn{3}{c|}{ HDFC (\%) } & \multicolumn{3}{c|}{ AXIS (\%) } & \multicolumn{3}{c|}{ INDUSIND (\%) } \\
\hline Variables & UG & G & PG & UG & G & PG & UG & G & PG & UG & G & PG \\
& & & & & & & & & & & & \\
ATM & 6 & 19 & 31 & 4 & 9 & 19 & 6 & 12 & 14 & 7 & 11 & 17 \\
Banking & $(10.7)$ & $(33.9)$ & $(55.4)$ & $(13)$ & $(28)$ & $(59)$ & $(19)$ & $(38)$ & $(44)$ & $(20)$ & $(31)$ & $(49)$ \\
\hline Branch & 8 & 16 & 19 & 5 & 10 & 15 & 8 & 7 & 9 & 4 & 6 & 8 \\
Banking & $(18.6)$ & $(37.2)$ & $(44.1)$ & $(17)$ & $(33)$ & $(50)$ & $(33)$ & $(29)$ & $(38)$ & $(22)$ & $(33)$ & $(44)$ \\
\hline Mobile & 7 & 12 & 12 & 2 & 5 & 7 & 4 & 3 & 6 & 3 & 6 & 9 \\
Banking & $(22.5)$ & $(38.7)$ & $(38.7)$ & $(14)$ & $(36)$ & $(50)$ & $(31)$ & $(23)$ & $(46)$ & $(17)$ & $(33)$ & $(50)$ \\
\hline Internet & 7 & 6 & 11 & 3 & 4 & 5 & 3 & 2 & 3 & 4 & 3 & 4 \\
Banking & $(29.1)$ & $(25)$ & $(45.8)$ & $(25)$ & $(33)$ & $(42)$ & $(38)$ & $(25)$ & $(38)$ & $(36)$ & $(27)$ & $(36)$ \\
\hline
\end{tabular}

Note: Figures in parenthesis denote \% to column total; UG-Under Graduate, G-Graduate and PGPostgraduate.

Source: Primary data from questionnaire and interviews.

\section{Testing of Hypotheses}

\subsection{Kruskal Wallis test}

This is a distribution-free non-parametric test used to compare three or more independent groups of sampled data statistics. Seven respondents from each of the four private banks (ICICI, HDFC, AXIS and INDUSIND Bank) were randomly sampled to determine whether customer's ranking of different banking services were the same. 
$\mathbf{H}_{\mathbf{0 1}}$ : Usefulness of banking services is the same for all the banks.

$\mathbf{H}_{\mathbf{a} 1}: \mathrm{H}_{01}$ is not true.

If null hypothesis is not true then chi-square value tends to get large and the hypothesis is rejected; vice versa otherwise. The ranks are from high value to low value of banking services.

Table 5: Frequency usage of banking services by respondents

\begin{tabular}{|l|l|c|c|c|c|}
\hline $\begin{array}{l}\text { Customer's } \\
\text { Usage } \\
\text { Variables }\end{array}$ & Categories & ICICI (\%) & HDFC (\%) & AXIS (\%) & $\begin{array}{l}\text { INDUSIND } \\
(\%)\end{array}$ \\
\hline Frequency of & Once in a day & $42(27)$ & $31(35)$ & $25(32)$ & $28(34)$ \\
usage & Thrice in a week & $73(47)$ & $32(32)$ & $38(49)$ & $34(41)$ \\
& Once in a week & $39(25)$ & $29(33)$ & $14(18)$ & $21(25)$ \\
\hline
\end{tabular}

Note: Figures in parenthesis denote \% to column total.

Source: Primary data from questionnaire and interviews.

The numbers in Table 5 show that the most frequent usage of banking services are: 35 per cent once in a day, 49 per cent of Axis respondent were found to use banking services thrice in a week, followed by ICICI bank (47 per cent), INDUSIND bank (41 per cent) and HDFC bank (32 per cent).

Table 6: Kruskal Wallis test to determine usefulness of banking services

\begin{tabular}{|l|l|c|c|l|}
\hline $\begin{array}{l}\text { S. } \\
\text { No. }\end{array}$ & Banking services & $\begin{array}{l}\text { Degree of } \\
\text { freedom } \\
\mathbf{( 4 - 1 = 3 )}\end{array}$ & $\begin{array}{l}\text { Kruskal } \\
\text { Wallis } \\
\text { test value }\end{array}$ & Result \\
\hline 1 & Cash Withdrawal & 3 & -63 & $\begin{array}{l}\text { Reject } \mathrm{H}_{01}, \chi^{2}<7.815 \text { at 5\% level } \\
\text { of significance }\end{array}$ \\
\hline 2 & $\begin{array}{l}\text { Tax, Insurance, Utility Bill } \\
\text { payments }\end{array}$ & 3 & -28.0 & $\begin{array}{l}\text { Reject } \mathrm{H}_{01}, \chi^{2}<7.815 \text { at 5\% level } \\
\text { of significance }\end{array}$ \\
\hline 3 & Account Balance & 3 & -55.1 & $\begin{array}{l}\text { Reject } \mathrm{H}_{01}, \chi^{2}<7.815 \text { at 5\% level } \\
\text { of significance }\end{array}$ \\
\hline 4 & Fund Transfer & 3 & -48.7 & $\begin{array}{l}\text { Reject } \mathrm{H}_{01}, \chi^{2}<7.815 \text { at 5\% level } \\
\text { of significance }\end{array}$ \\
\hline 5 & $\begin{array}{l}\text { Investment information and } \\
\text { Online loan related information }\end{array}$ & 3 & -58.9 & $\begin{array}{l}\text { Reject } \mathrm{H}_{01}, \chi^{2}<7.815 \text { at } 5 \% \text { level } \\
\text { of significance }\end{array}$ \\
\hline 6 & $\begin{array}{l}\text { Download online forms } \\
\text { E-ticketing }\end{array}$ & 3 & -47.3 & $\begin{array}{l}\text { Reject } \mathrm{H}_{01}, \chi^{2}<7.815 \text { at } 5 \% \text { level } \\
\text { of significance }\end{array}$ \\
\hline 7 & $\begin{array}{l}\text { E-28.0 } \\
\text { Reject } \mathrm{H}_{01}, \chi^{2}<7.815 \text { at } 5 \% \text { level } \\
\text { of significance }\end{array}$ \\
\hline
\end{tabular}

Source: Primary data from questionnaire and interviews.

Compare this to 33 per cent of HDFC respondents are found to use banking services once a week, followed by HDFC bank (33 per cent), ICICI and INDUSIND bank ( 25 per cent each). 
Table 6 shows that Chi-square value is less than Kruskal Wallis Test value for all the variables. So, the null hypothesis $\left(\mathrm{H}_{01}\right)$ is rejected in favor of alternate hypothesis $\left(\mathrm{H}_{\mathrm{a} 1}\right)$. This means there is a significance difference in the usefulness of banking services among the four private sector banks in India.

\subsection{Chi-Square Test}

The chi-square values are used to test the significance of association between two attributes. The data gathered are rated on 5-point Likert scale. The results so obtained are tabulated based on their specific factors. The banking services were classified into four major categories: ATM banking, branch banking, internet banking and mobile banking with their variable factors. The results are given the in the Table 7.

In order to test the hypothesis based on the above mentioned four banking services, we use chi-square values to find the significance of the responses attributed by the respondents. The summarized results of the chi-square test values at 5 per cent level of significance are given in Table 8.

$\mathbf{H}_{\mathbf{0 2}}$ : There is a significant difference between characteristics of ATM banking services provided by different private banks to the customers.

$\mathbf{H}_{\mathbf{a} 1}: \mathrm{H}_{02}$ is not true.

The test results are shown in Table 8. It shows that at 5 per cent level of significance, the calculated value (1.956) is less than the tabulated value (21.026). So, the null hypothesis is rejected. This reveals that there is no significant difference between ATM banking services provided by different private bank's adoption of IT banking services by customers.

$\mathbf{H}_{\mathbf{0 3}}$ : There is a significant difference between branch banking services and customer satisfaction.

$\mathbf{H}_{\mathbf{a} 3}: \mathrm{H}_{03}$ is not true

Table 8 shows that at 5 percent significance level, the calculated value (1.000326) is less than the tabulated value (16.919). So, the null hypothesis $\left(\mathrm{H}_{03}\right)$ is rejected. This reveals that there is no significant difference between Branch Banking Services provided by different private banks to the adoption of IT banking services by customers. 
Table 7: Customer adoption of banking services

\begin{tabular}{|c|c|c|c|c|c|}
\hline Factor & ATM Banking & ICICI & HDFC & AXIS & INDUSIND \\
\hline F1 & Convenient location & 81.42 & 76.87 & 76.87 & 76.57 \\
\hline $\bar{F} 2$ & Ease of use & 78.57 & 81.25 & 75.62 & 76.00 \\
\hline F3 & $24 * 7$ Environment of operation & 83.92 & 82.50 & 75.00 & 76.00 \\
\hline $\mathrm{F} 4$ & Variety of transactions at ATM network & 85.71 & 78.75 & 72.50 & 69.14 \\
\hline \multirow[t]{2}{*}{ F5 } & Accurate records of all transaction & 88.57 & 77.5 & 71.25 & 68.00 \\
\hline & Branch Banking & & & & \\
\hline F1 & Friendliness of bank personnel & 80.9302 & 78 & 80 & 77 \\
\hline F2 & Bank branch's reputation & 82.7907 & 80 & 78.5167 & 75 \\
\hline F3 & Time taken to process the transaction & 84.1860 & 80.6666 & 86.3157 & 78 \\
\hline \multirow[t]{2}{*}{$\mathrm{F} 4$} & Working hours & 85.1162 & 81.3333 & 73.1100 & 73 \\
\hline & Internet Banking & & & & \\
\hline F1 & Page set up/menu flow & 82.58065 & 81.42857 & 81.33333 & 71.11111 \\
\hline $\mathrm{F} 2$ & Speed of page loading & 79.35484 & 81.42857 & 77.33333 & 68.88889 \\
\hline F3 & Easy of use/navigation & 83.22581 & 72.85714 & 79.33333 & 67.77778 \\
\hline F4 & Convenient hours of operation & 76.12903 & 80 & 79.33333 & 72.22222 \\
\hline F5 & Variety of transaction & 83.87097 & 74.28571 & 81.33333 & 76.66667 \\
\hline F6 & Real time access to information & 80.64516 & 72.85714 & 84 & 77.77778 \\
\hline F7 & Accurate records of all transaction & 80 & 80 & 73.33333 & 81.11111 \\
\hline \multirow[t]{2}{*}{ F8 } & $\begin{array}{l}\text { Support service(customer } \\
\text { feedback/complaint management services) }\end{array}$ & 80.64516 & 77.14286 & 80.66667 & 73.33333 \\
\hline & Mobile Banking & & & & \\
\hline F1 & Call Answering Time & 83.33333 & 80 & 81.36364 & 70.90909 \\
\hline $\mathrm{F} 2$ & Flawless/Correct options & 83.33333 & 71.66667 & 77.67442 & 67.27273 \\
\hline F3 & $\begin{array}{l}\text { Understanding and replying queries } \\
\text { quickly }\end{array}$ & 82.5 & 76.66667 & 73.02326 & 69.09091 \\
\hline F4 & Communication skill/positive approach & 82.5 & 75 & 72.27273 & 76.36364 \\
\hline F5 & $\begin{array}{l}\text { Educate customers how to use options of } \\
\text { different delivery channel }\end{array}$ & 81.66667 & 75 & 73.48837 & 76.36364 \\
\hline
\end{tabular}

$\mathbf{H}_{\mathbf{0 4}}$ : There is a significant difference between Internet banking services provided by different private banks to the adoption of IT banking services by customers.

$\mathbf{H}_{\mathbf{a} 4}: \mathrm{H}_{04}$ is not true 
As shown in the Table 8, at 5 percent significance level, the calculated value (3.959) is less than the tabulated value (32.671). So, the null hypothesis $\left(\mathrm{H}_{04}\right)$ is rejected. This reveals that there is no significant difference between internet banking services provided by different private banks to the adoption of IT banking services by customers.

$\mathbf{H}_{05}$ : There is a significant difference between mobile banking services provided by different private banks to the adoption of IT banking services by customers.

$\mathbf{H}_{\mathbf{a} 5}: \mathrm{H}_{\mathrm{a} 5}$ is not true

As shown in the Table 8, at 5 percent significance level, the calculated value (1.774) is less than the tabulated value (21.026). So, the null hypothesis is rejected. This reveals that there is no significant difference between mobile banking services provided by different private banks to the adoption of IT banking services by customers.

Table 8: Testing of hypotheses $\left(\chi^{2}\right.$ Test $)$

\begin{tabular}{|c|c|c|c|c|l|c|c|}
\hline $\begin{array}{l}\text { Level of } \\
\text { Significance }\end{array}$ & $\begin{array}{l}\text { Number } \\
\text { of Rows }\end{array}$ & $\begin{array}{l}\text { Number } \\
\text { of } \\
\text { Columns }\end{array}$ & $\begin{array}{l}\text { Degrees of } \\
\text { Freedom }\end{array}$ & p-Value & $\begin{array}{l}\text { Calculated } \\
\text { value }\end{array}$ & $\begin{array}{l}\text { Tabulated } \\
\text { value }\end{array}$ & Result \\
\hline 0.05 & 5 & 4 & 12 & 0.9994 & 1.956361 & 21.026 & $\begin{array}{c}\text { Reject } \\
\mathrm{H}_{02}\end{array}$ \\
\hline 0.05 & 4 & 4 & 9 & 0.9994 & 1.000326 & 16.919 & $\begin{array}{c}\text { Reject } \\
\mathrm{H}_{03}\end{array}$ \\
\hline 0.05 & 8 & 4 & 21 & 0.9999 & 3.959468 & 32.671 & $\begin{array}{c}\text { Reject } \\
\mathrm{H}_{04}\end{array}$ \\
\hline 0.05 & 5 & 4 & 12 & 0.9996 & 1.774393 & 21.026 & $\begin{array}{c}\text { Reject } \\
\mathrm{H}_{05}\end{array}$ \\
\hline
\end{tabular}

Table 9: Adoption of information technology and customer satisfaction $\left(\chi^{2}\right.$ Test $)$

\begin{tabular}{|c|c|l|l|l|l|l|c|}
\hline $\begin{array}{l}\text { Level of } \\
\text { Significance }\end{array}$ & $\begin{array}{l}\text { Number } \\
\text { of Rows }\end{array}$ & $\begin{array}{l}\text { Number } \\
\text { of } \\
\text { Columns }\end{array}$ & $\begin{array}{l}\text { Degrees } \\
\text { of } \\
\text { Freedom }\end{array}$ & $\begin{array}{l}\text { p- } \\
\text { Value }\end{array}$ & $\begin{array}{l}\text { Calculated } \\
\text { value }\end{array}$ & $\begin{array}{l}\text { Tabulated } \\
\text { value }\end{array}$ & Result \\
\hline 0.05 & 13 & 4 & 36 & 1 & 5.4870 & 79.083 & $\begin{array}{c}\text { Reject } \\
\mathrm{H}_{06}\end{array}$ \\
\hline
\end{tabular}

$\mathbf{H}_{\mathbf{0 6}}$ There is a significant difference between adoption of information technology and customer satisfaction.

$\mathbf{H}_{\mathbf{a} 6}: \mathrm{H}_{06}$ is not true. 
Table 9 shows the result of the Chi-square test used at 5 percent significance level. The result reveals that the calculated value (5.4870) is less than the tabulated value (79.083). So, the null hypothesis $\left(\mathrm{H}_{06}\right)$ is rejected. This reveals that there is no significant difference between adoption of Information Technology and Customer satisfaction.

$\mathbf{H}_{\mathbf{0 7}}$ : There is a significant difference between benefits of IT banking services and customer satisfaction as compared in different banks.

$\mathbf{H}_{\mathbf{a} 7}: \mathrm{H}_{07}$ is not true

Factors responsible for adoption of IT banking services among customers include it provide faster, easier, reliable and continuous access to information, Second, it reduces cost in accessing and using the banking services; easy to learn (increased automation of process); fourth, better management of services (easy to follow up requests/complaints).

Table 10 shows that as per the chi-square test used at 5 percent significance level, the result reveals that the calculated value $(0.462)$ is less than the tabulated value (21.026). So, the null hypothesis is rejected indicating that there is no significant difference between adoption of information technology and customer satisfaction as compared in different banks.

Table 10: Benefits of IT services for respondents $\left(\chi^{2}\right.$ Test $)$

\begin{tabular}{|l|l|l|l|l|l|l|l|}
\hline $\begin{array}{l}\text { Level of } \\
\text { Significance }\end{array}$ & $\begin{array}{l}\text { Number } \\
\text { of Rows }\end{array}$ & $\begin{array}{l}\text { Number } \\
\text { of } \\
\text { Columns }\end{array}$ & $\begin{array}{l}\text { Degrees } \\
\text { of } \\
\text { Freedom }\end{array}$ & $\begin{array}{l}\text { p- } \\
\text { Value }\end{array}$ & $\begin{array}{l}\text { Calculated } \\
\text { value }\end{array}$ & $\begin{array}{l}\text { Tabulated } \\
\text { value }\end{array}$ & Result \\
\hline 0.05 & 5 & 4 & 12 & 0.9999 & 0.461701 & 21.026 & $\begin{array}{l}\text { Reject } \\
\mathrm{H}_{07}\end{array}$ \\
\hline
\end{tabular}

$\mathbf{H}_{\mathbf{0 8}}$ : There is a significant difference between unwillingness to use e-channel and customer dissatisfaction.

$\mathbf{H}_{\mathbf{a} 8}: \mathrm{H}_{08}$ is not true.

The IT banking services has many benefits but there are many factors that inhibit adoption of IT banking services. These are: lack of awareness/knowledge about internet technology and accessibility of service, increase in fraud due to inefficient safety and security features, slow transfer speed, and delay in transmission due to machine breakdown / machine complexity/technical failure. 
Table 11: Respondents' Unwillingness to Use E-Channel for Commercial Purpose $\left(\chi^{2}\right.$ Test $)$

\begin{tabular}{|l|l|l|l|l|l|l|l|}
\hline $\begin{array}{l}\text { Level of } \\
\text { Significance }\end{array}$ & $\begin{array}{l}\text { Number } \\
\text { of Rows }\end{array}$ & $\begin{array}{l}\text { Number } \\
\text { of } \\
\text { Columns }\end{array}$ & $\begin{array}{l}\text { Degrees } \\
\text { of } \\
\text { Freedom }\end{array}$ & $\begin{array}{l}\text { p- } \\
\text { Value }\end{array}$ & $\begin{array}{l}\text { Calculated } \\
\text { value }\end{array}$ & $\begin{array}{l}\text { Tabulated } \\
\text { value }\end{array}$ & Result \\
\hline 0.05 & 4 & 4 & 9 & 0.9972 & 1.487 & 16.919 & $\begin{array}{l}\text { Reject } \\
\mathrm{H}_{08}\end{array}$ \\
\hline
\end{tabular}

Table 11 shows that, at 5 per cent significance level, the calculated value (1.487) is less than the tabulated value (16.919). So, the null hypothesis $\left(\mathrm{H}_{08}\right)$ is rejected. This reveals that there is no significant difference between unwillingness to use e-channel and customer dissatisfaction.

\section{Conclusion}

Customers of private sector banks agree that there exist relationship between factors such as age, gender, income, qualification and adoption of banking technology by customers. Young generation belonging to a category of 30-45 years finds the services comfortable, friendly and easy to use. Customers with post-graduate and graduate qualifications are found to be mostly adaptors of IT banking services

It is reflected from the survey that ATM banking remains the most popular banking service among customers after branch banking, mobile banking and internet banking respectively as they provide convenience, privacy, security, ease of use, real time accessibility, and accurate record of various transaction.

Kruskal Wallis test applied to the data collected ensures that customer's usage of different banking services is same for all the banks. From these, it is clear that there is no significant difference between ATM banking, branch banking, mobile banking and internet banking services provided by different private banks to the customers. There is a relation between benefits of banking services and increasing banking technology adoption. Customer's unwillingness to use e-channel for commercial purpose decreases banking technology adoption.

Author Information: Submitting author is Bindiya Tater, research scholar, Suresh Gyan Vihar University, Jaipur, Rajasthan-India, Email Id: bindiya.tater@gmail.com, Contact no: 919602026899. Manish Tanwar is Assistant Professor, Rampuria Jain College, Bikaner (Raj) India, Email Id:imanishtanwar@gmail.com, Contact No: 91-941-309-2282 and Krishna Murari 
is Corresponding author and Assistant Professor at MITS University, Laxmangarh, Sikar, Raj, India, Email: krishnamurari_1980@rediffmail.com, contact No.-91-9983733735

\section{References}

Ajzen, I. and Fishbein, M., (1980). Understanding Attitudes and Predicting Social Behavior ( $3^{\text {rd }}$ Ed.). Englewood Cliffs, Prentice-Hall, London.

Al-Sabbagh, I., and Molla, A., (2004). Adoption and use of internet banking in the sultanate ofOman: an exploratory study. Journal of Internet Banking and Commerce, 9: 1-7.

Davis, F., (1986). A Technology Acceptance Model for Empirically Testing New EndUserInformation Systems: Theory and Results. MIT. Ph.D. Thesis, Boston.

Fishbein, M. and Ajzen, I., (1975). Belief, Attitude, Intention, and Behavior: An Introduction to Theory and Research. Addison-Wesley, Boston.

Hain, D., Tootell, H. and Alcock C., (2002). Understanding attitudes towards internet banking. Seventh Annual Collector Conference on Electronic Commerce, Melbourne, Australia,

Heikki, K., Minna, M. and Taplo, P., (2002). Factors underlying attitude formation towards online banking in Finland. The International Journal of Bank Marketing, 20: 261-272.

Kalfan, A., Al-Refaei, Y., Al-Hajry, M., (2006). Factors influencing the adoption of Internet Banking in Oman: A descriptive case study analysis. International Journal of Financial Services Management, 1: 155-172.

Marlin, S., (2005). Banking for the 21st century, Bank Systems and Technology, July 1.

Perumal, V., and Shanmugam B., (2004), Internet banking: boon or bane, Journal of Internet Banking and Commerce, 9: 1-6,

Ramsay, J., and Smith, M., (1999). Managing consumer channel usage in the Australian banking sector, Managerial Auditing Journal, 14: 32-33,

Sohail, S. M., and Shanmugam, B., (2002). Electronic banking and customer preferences in Malaysia: An empirical investigation, Fourth Conference on Information \& Computer Science, King Fahd University of Petroleum \& Minerals, Saudi Arabia, 355-364

Tan, M., and Teo, T., (2000). Factors influencing the adoption of internet banking. Journal of the Association for Information Systems 1: 1-42.

Wan, W.N., Luk, C.L., and Chow C.W.C., (2005). Consumers' adoption of banking channels in Hong Kong. International Journal of Bank Marketing, 23: 255-272.

Wang, Y., Wang, Y., Lin, H. and Tang, T., (2003). Determinants of user acceptance of internet banking: An empirical study. International Journal of Service Industry Management 14: 501519. 